\title{
BAP effect in vitro germination of soybean cultivars UFUS Xavante an UFUS Carajás
}

\author{
Ana Paula Rodrigues Gomes, Ana Paula Oliveira Nogueira*, Giovanna Dias De Sá, Bárbara Rodrigues, \\ Ana Maria Bonetti \\ From 5th Congress of the Brazilian Biotechnology Society (SBBIOTEC) \\ Florianópolis, Brazil. 10-14 November 2013
}

\section{Background}

Plant tissue culture is a biotechnology particularly relevant to plant genetic transformation. The ability of in vitro regeneration is one of the requirements for the production of usable plants in breeding programs [1]. As each genotype has a specific regeneration potential, several protocols have been developed with the aim of developing methodologies that can speed up the germination process [2]. In vitro, culture media for plants, not only provide macro and micronutrients, but also carbohydrates, usually sucrose as a carbon source. Better results are obtained by adding organic compounds such as vitamins, amino acids and growth regulators [3].

\section{Methods}

This study evaluated the germination of seeds of two soybean cultivars on MS medium with different concentrations of $0,1,3$ and $5 \mu \mathrm{g} / \mathrm{L}$ BAP. The cultivars used were UFUS Xavante and UFUS-Carajás from the Breeding Program Soybean by Federal University of Uberlândia. Seeds were placed in a solution of alcohol/water $70 \%$ $(\mathrm{v} / \mathrm{v})$ for $1 \mathrm{~min}$ and then immersed in $0.5 \%$ sodium hypochlorite $(\mathrm{w} / \mathrm{v})$ for $30 \mathrm{~min}$. After surface sterilization, the seeds will be washed with distilled water and autoclaved. After desinfestation (quoting the type of disinfection) seeds of cultivars were soaked in distilled water autoclaved for a period of 1 and 7 days. Subsequently, the seeds were inoculated in test tubes with the medium remains under dark for 7 days. The evaluations were done every 7 days for 28 days [4].

\section{Results and conclusions}

We evaluated the occurrence of rupture of the radicle and seedling formation. After 7 days it was observed that the cultivar UFUS-Xavante that were soaked in water for one day and inoculated in medium with $3 \mu \mathrm{g} / \mathrm{L}$ BAP showed $100 \%$ of germination. On the other hand, the soaking for 7 days led to a decrease in germination percentage $(80 \%)$ independent of the hormone concentration. At 14 days, there was the emergence of the cotyledons for both cultivars in medium with $3 \mu \mathrm{g} /$ L BAP and with 21 days, there was the formation of seedlings in this regulator concentration. It was observed that increasing the regulator concentration associated with prolonged soaking conditions were not favorable for both varieties. New regulators combinations are necessary to assess the effect of the growth regulator and the time soybean's formation seedlings in vitro. Keywords:.

Published: 1 October 2014

\section{References}

1. Sediyama T, Teixeira RC, Barros HB: Origem, evolução e importância econômica. In Tecnologias de produção e usos da soja. Londrina: Mecenas; Sediyama, T 2009:1-5.

2. Andrade SRM: Princípios da cultura de tecidos. Documentos EMBRAPA Planaltina, dez 2002.

3. Grattapaglia D, Machado MA: Micropropagação. In Cultura de tecidos e transformação de genética de plantas. Brasília: EMBRAPA-CBAB;Torres AC, Caldas LS, Buso JA 1998:331-353.

4. Oliveira PV, Benbadis KA, Carvalho ACPP: Avaliação da regeneração in vitro de explantes de caupi e soja. Revista Ciência Agronômica 2006, 37(2):153-159.

doi:10.1186/1753-6561-8-S4-P91

Cite this article as: Rodrigues Gomes et al:: BAP effect in vitro germination of soybean cultivars UFUS Xavante an UFUS Carajás. BMC Proceedings 2014 8(Suppl 4):P91. 